\title{
DO LIMBO AO PÂNTANO: UM PERCURSO DE UM PROJETO DE PESQUISA ${ }^{1}$
}

\author{
Eder Sumariva Rodrigues ${ }^{2}$ \\ André Carreira (orientador)
}

\begin{abstract}
RESUMO : Esta comunicação visa apresentar o percurso da pesquisa realizado neste $1^{\circ}$ semestre no Programa de Pós-Graduação em Teatro. Não é segredo para ninguém que a maioria dos mestrandos tenha que realizar modificações em seu projeto de pesquisa em virtude da delimitação do objeto de pesquisa, dos referentes da metodologia a ser aplicada, da revisão bibliográfica que muitas vezes é escassa e tantos outros aspectos que interferem em um projeto de pesquisa.
\end{abstract}

PALAVRAS-CHAVE : Teatro de Grupo ; Pesquisa Teatral ; Fontes.

Esta comunicação visa apresentar o percurso da pesquisa realizado neste 1 semestre no Programa de Pós-Graduação em Teatro. Não é segredo para ninguém que a maioria dos mestrandos tenha que realizar modificações em seu projeto de pesquisa em virtude da delimitação do objeto de pesquisa, dos referentes da metodologia a ser aplicada, da revisão bibliográfica que muitas vezes é escassa e tantos outros aspectos que interferem em um projeto de pesquisa.

Durante o primeiro semestre deste ano, no contexto da disciplina Seminário de Pesquisa pude identificas dificuldades com relações a fontes de pesquisa que poderiam comprometer o trabalho final num todo o que me impulsionou a buscar a reformulação do mesmo. Realizei então um giro completo na minha pesquisa.

O objetivo que orienta meu mestrado é investigar quais são as "raízes" do Teatro de Grupo no Brasil. Essa questão que julgo importante para a pesquisa teatral brasileira busca delimitar o tempo histórico no qual este novo modelo de organização teatral se definiu, ou definiu seu terreno.

\footnotetext{
${ }^{1}$ Comunicação apresentada no XVII Congreso Internacional de Teatro Iberoamericano y Argentino, realizado de 5 a 9 de agosto de 2008 em Buenos Aires. Organizado pelo Instituto de Historia del Arte Argentino y Latinoamericano "Luis Ordaz", Facultad de Filosofía y Letras de la Universidad de Buenos Aires.

${ }^{2}$ Aluno regular do PPGT - Mestrado em Teatro/ CEART-UDESC. Ingresso no PPGT em março de 2008, sob orientação do prof. Dr. Andréa Carreira.
} 
No primeiro momento investiguei elementos referentes à constituição e formulação das matrizes dos grupos teatrais no início do século $X X$, tratei principalmente de identificar a influência de Louis Jouvet neste processo de organização dos projetos dos grupos brasileiros. O Brasil, neste período, teve grande influência do universo teatral francês, principalmente no que se diz respeito à estética, técnicas e modelos de atuação teatral. Neste contexto, fato importante que contribuiu para a disseminação da cena francesa no Brasil foi à turnê de Louis Jouvet (discípulo de Jacques Copeau e que anteriormente marcou presença na Argentina influenciando grande parte da América Latina) e que incluiu uma estada de 4 meses no Rio de Janeiro e São Paulo em 19413. Valer ressaltar que a Cia de Jouvet foi considerada exemplo de organização quando partiu da França. A partir desta informação, o primeiro passo da pesquisa foi mapear quais as influências da companhia de Jouvet na constituição de grupos brasileiros.

Em maio deste ano realizei uma pesquisa de campo para a coleta de materiais e documentos na cidade do Rio de Janeiro com o fim de formular a base teórica do projeto. Nesta viagem, foi possível realizar uma investigação nos arquivos da Fundação Nacional das Artes (FUNARTE) na qual se encontra importante acervo bibliográfico da história das artes cênicas no Brasil; a Maison du France (Consulado Francês) que disponibiliza através da Mediateca um acervo dedicado à cultura francesa; a Biblioteca Nacional que detém um vasto acervo de materiais jornalísticos da época; o Theatro Municipal do Rio de Janeiro que possui o programa original da peça editado em 1941 e o Arquivo do Estado do Rio de Janeiro.

Nestes locais foi possível entrar em contato com uma diversidade de materiais: jornais da época, obras raras (Revista Dom Casmurro e Comoédia) e livros originais publicados por Louis Jouvet. Na mesma ocasião pude realizar uma conversa informal com as professoras Tânia Brandão e Maria Helena Werneck do Departamento de Teoria Teatral do Programa de Pós-Graduação em Teatro da UNIRIO. Estas consultas me possibilitaram colocar em xeque a minha hipótese ou

\footnotetext{
${ }^{3}$ Jouvet teve que ampliar sua estadia na América Latina devido a $2^{\circ}$ Guerra Mundial e não pode retornar à França por que todos os portos estavam fechados.
} 
pelo menos refletir sobre a possibilidade de aprofundá-la frente aos materiais disponíveis.

Ao retornar e analisar o material coletado, pude comprovar que o mesmo não possuía densidade de informações necessárias para fundamentar e sustentar meu projeto de pesquisa. Para tal pesquisa, eu necessitaria de um constante contato com as fontes, como um "trabalho de detetive" conforme disse a professora Maria Helena Werneck. Considerando a distância Florianópolis onde eu vivo e o Rio de Janeiro; o prazo de conclusão da dissertação; importantes integrantes de grupos de teatro que tiveram contato com Jouvet, já faleceram, percebi a necessidade de reorganizar meu objeto de pesquisa. Realizar esta transição implicou em um exercício de desapego do objeto de pesquisa e como também na reformulação que nasceu de percepção de um limbo, lugar na qual todo mestrando parece refletir. Foi a partir disso que tive que identificar um novo caminho a trilhar.

Motivado ainda pela investigação sobre o fenômeno teatral do Teatro de Grupo e quais seus princípios, decidi adentrar no teatro anos 80, outra época importante para compreender a articulação deste modelo de trabalho grupal.

Nesta década, houve uma grande circulação de grupos estrangeiros no Brasil, período que podemos chamar de pós ditadura e ao mesmo tempo começavam a surgir muitos grupos que já buscavam realizar pesquisas estéticas. Neste contexto destaca-se a presença das atrações do $3^{\circ}$ Festival Internacional promovido pela Ruth Escobar ${ }^{4}$ em1981: a presença do grupo norte-americano Mabu Mines; o belga Plan K; o La Cuadra, de Sevilla; uruguaio Galpón, português A. Comuna. Pode-se destacar ainda a vinda do Linving Theatre no final dos anos 70e Odin Teatret na metade da década de 80 o que representou importantes colaborações para o teatro brasileiro sobretudo na proposição de modelos de grupos de trabalho

No Brasil,na década de 80, pode destacar ainda a atuação dos grupos: Boi Voador, Pessoal do Vitor, Pessoal do Cabaré, Lume, Galpão, Oi Nois Aqui

${ }^{4}$ Festival realizado de 1974 a 1981. Segundo Edélcio Mostaço nunca foi adequadamente avaliado o impacto destes festivais em SP. Nas edições anteriores estavam presentes o espanhol Els Joglars, o Grupo Experimental de Cali da Colômbia e Jacques Lebreton 
Traveiz, Pod Minoga, Imbuaça, Oikoveva, Alegria/Alegria, Teatro Popular União e Olho Vivo, Piolim, Fora do Sério, XPTO e tantos outros deste período.

Realizar estas aproximações entre grupos estrangeiros e brasileiros pode proporcionar o preenchimento de uma lacuna de nossa história, pois apesar de haver textos sobre grupos teatrais brasileiros, essa década ainda não foi tratada de forma panorâmica. $O$ trabalho de Rosyane Trotta apresenta uma reflexão importante bem como os estudos de Silvia Fernandes XXXX. Considerando, no entanto que é necessário tomar os grupos anos 80 como um momento particular, pois o trabalho destes grupos constitui o campo que hoje reconhecemos com Teatro de Grupo.

Acredito que, 0 atual objeto de pesquisa, que ainda encontra-se em reformulação, possibilitará uma reflexão sobre a organização teatral tomando como elemento instrumental a influência dos grupos estrangeiros nas estruturas dos grupos brasileiros. Neste sentido, considero que é possível compreender melhor o fenômeno do Teatro de Grupo e suas repercussões na história do Teatro Brasileiro.

Agora necessito jogar-me no pântano. 